\title{
Influence of Uremia and Hemodialysis on the Turnover
}

\section{and Metabolic Effects of Glucagon}

\author{
Robert S. Sherwin, Christine Bastl, Fredric O. Finkelstein, \\ Merrick Fisher, Henry Black, Rosa Hendler, and Phimip Felic \\ From the Department of Internal Medicine, Yale University School of Medicine, \\ New Haven, Connecticut 06510
}

A B S T R A C T To evaluate the mechanism and role of hyperglucagonemia in the carbohydrate intolerance of uremia, 19 patients with chronic renal failure (12 of whom had undergone chronic hemodialysis for at least $11 \mathrm{mo})$ and 35 healthy control subjects were studied. Plasma glucagon, glucose, and insulin were measured in the basal state, after glucose ingestion (100 g), after intravenous alanine $(0.15 \mathrm{~g} / \mathrm{kg})$, and during a $3-\mathrm{h}$ continuous infusion of glucagon $(3 \mathrm{ng} / \mathrm{kg}$ per $\mathrm{min}$ ) which in normal subjects, raised plasma glucagon levels into the upper physiological range.

Basal concentrations of plasma glucagon, the increment in glucagon after infusion of alanine, and postglucose glucagon levels were three- to fourfold greater in uremic patients than in controls. The plasma glucagon increments after the infusion of exogenous glucagon were also two- to threefold greater in the uremics. The metabolic clearance rate (MCR) of glucagon in uremics was reduced by $58 \%$ as compared to controls. In contrast, the basal systemic delivery rate (BSDR) of glucagon in uremics was not significantly different from controls.

Comparison of dialyzed and undialyzed uremics showed no differences with respect to plasma concentrations, MCR, or BSDR of glucagon. However, during the infusion of glucagon, the increments in plasma glucose in undialyzed uremics were three- to fourfold greater than in dialyzed uremics or controls. When the glucagon infusion rate was increased in controls to $6 \mathrm{ng} / \mathrm{kg}$ per min to produce increments in plasma glucagon comparable to uremics, the glycemic response remained approximately twofold greater in the undialyzed uremics. The plasma glucose response to glu-

Dr. Felig is the recipient of a Research Career Development Award (AM 70219) from the National Institutes of Health.

Received for publication 2 September 1975 and in revised form 23 October 1975. cagon in the uremics showed a direct linear correlation with oral glucose tolerance which was also improved with dialysis. The glucagon infusion resulted in a $24 \%$ reduction in plasma alanine in uremics but had no effect on alanine levels in controls.

It is concluded that $(a)$ hyperglucagonemia in uremia is primarily a result of decreased catabolism rather than hypersecretion of this hormone; $(b)$ sensitivity to the hyperglycemic effect of physiological increments in glucagon is increased in undialyzed uremic patients; and (c) dialysis normalizes the glycemic response to glucagon, possibly accounting thereby for improved glucose tolerance despite persistent hyperglucagonemia. These findings thus provide evidence of decreased hormonal catabolism contributing to a hyperglucagonemic state, and of altered tissue sensitivity contributing to the pathophysiological action of this hormone.

\section{INTRODUCTION}

Chronic renal failure is characterized by an increased incidence of glucose intolerance (1-3). The role of insulin resistance in the pathogenesis of the carbohydrate intolerance in uremia has recently been emphasized (4). Decreased sensitivity to the hypoglycemic effects of endogenous $(2,5,6)$ and exogenous $(3,5-8)$ insulin has been observed in uremic man, whereas basal and glucose-stimulated insulin concentrations are normal or increased $(1-3,5,6,9)$. After chronic dialysis, glucose tolerance generally improves in association with increased tissue sensitivity to insulin $(5,9-13)$. The mechanism of uremia-induced insulin resistance and the improvement in insulin sensitivity after dialysis has not been established. Recently, Bilbrey et al. (14) observed increased levels of circulating glucagon, a known insulin antagonist, in chronic renal failure. The pathophysiological significance of these findings was questioned however, since dialysis resulted in marked im- 
provement in glucose tolerance despite unchanged levels of plasma glucagon (14). The possible role of altered tissue responsiveness to physiological increments of glucagon in uremia and the effect of dialysis on glucagon sensitivity have not been previously examined. Furthermore, whether hyperglucagonemia in uremia is a consequence of increased secretion or is solely due to reduced hormone catabolism has not been determined.

The present study was consequently undertaken to examine the turnover of plasma glucagon and the tissue responsiveness to physiological increments in glucagon in uremia. In the evaluation of glucagon kinetics and sensitivity, special attention was given to the influence of dialysis on these parameters. The data indicate that hyperglucagonemia in uremia is a result of decreased turnover rather than hypersecretion. Furthermore, uremia is associated with increased sensitivity to the hyperglycemic effects of glucagon. This increased tissue sensitivity to glucagon returns to normal after chronic dialysis.

\section{METHODS}

\section{Subjects}

Two groups of subjects were studied. The control group consisted of 35 healthy, nonobese volunteers (18 males and 17 females) within $15 \%$ of ideal body weight (based on 1959 Metropolitan Life Insurance Company tables). The subjects ranged in age from 18 to $50 \mathrm{yr}$. They consumed weight-maintaining diets containing at least $200 \mathrm{~g}$ of carbohydrate and were taking no drugs. All had negative primary family histories for diabetes mellitus and none had an elevated fasting plasma glucose. 20 of the subjects received an oral glucose tolerance test $(100 \mathrm{~g})$ and all demonstrated a normal response (15).

The uremic group consisted of 19 ambulatory patients (12 males and 7 females) with chronic renal failure, aged

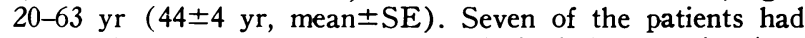
not undergone treatment with dialysis before study (undialyzed group). 12 patients had undergone chronic hemodialysis for at least $11 \mathrm{mo}$ in the dialysis unit of the YaleNew Haven Hospital before study. None of the uremic patients had evidence of an acute medical illness or peripheral edema at the time of study. None were receiving corticosteroids. The medications received by dialyzed and undialyzed groups were similar with the exception that 9 of 12 dialyzed subjects and 2 of 7 undialyzed subjects received parenteral androgens. All but three uremic subjects were within $15 \%$ of ideal body weight (based on 1959 Metropolitan Life Insurance Company tables). The patients consumed weight-maintaining diets containing at least $250 \mathrm{~g}$ of carbohydrate for 3 days before study. Dialyzed patients consumed approximately $80 \mathrm{~g}$ of protein, while undialyzed patients were restricted to $50-60 \mathrm{~g}$ of protein. Pertinent laboratory data in the uremic group included: serum creatinine, which ranged from 7.5 to $25.1 \mathrm{mg} / 100 \mathrm{ml}$ (15.6 \pm 1.2 , mean $\pm S E)$; serum potassium, 4.0-6.9 meq/liter (5.3 \pm 0.2 , mean $\pm \mathrm{SE})$; serum bicarbonate, $11.5-25.0 \mathrm{meq} /$ liter $(18.6$ \pm 1.0 , mean $\pm \mathrm{SE})$; serum calcium, $6.3-10.4 \mathrm{mg} / 100 \mathrm{ml}(8.6$ \pm 0.2 , mean $\pm \mathrm{SE})$; and serum phosphate $3.2-14.4 \mathrm{mg} / 100$ $\mathrm{ml}(6.5 \pm 0.6$, mean $\pm \mathrm{SE})$. There were no significant differ- ences with respect to these laboratory values, ages, or weights between the dialyzed and undialyzed patients.

\section{Procedures}

All subjects were studied in the postabsorptive state after a 12-15-h overnight fast. Uremic subjects were instructed to omit all medications on the day of study. Dialysis patients were studied just before their next dialysis. An indwelling catheter was inserted in an antecubital vein for blood sampling. An additional catheter was inserted in the contralateral vein or ateriovenous fistula during the glucagon-infusion studies. Subjects were recumbent for at least $20-30$ min before study. At least two control blood samples were obtained at $10-15-\mathrm{min}$ intervals before glucose, alanine, or glucagon administration. Control values presented in each study represent the mean of the base-line determinations. Three types of procedures were employed.

Oral glucose tolerance. A $100-\mathrm{g}$ oral glucose tolerance test was performed in 20 normal and 10 uremic subjects. In this study, blood samples were drawn at $30-60$-min intervals for $3 \mathrm{~h}$ after ingestion of $100 \mathrm{~g}$ glucose dissolved in $200 \mathrm{ml}$ of water.

Alanine infusion. L-Alanine (Nutritional Biochemical Corp., Cleveland, Ohio) was given intravenously $(0.15 \mathrm{~g} / \mathrm{kg}$ body weight) over 2-4 min to 21 normal and 9 uremic subjects. Methods used in the preparation of the alanine infusate have previously been described (16). Blood samples were obtained at $10-30$-min intervals for $90 \mathrm{~min}$ after the infusion of alanine.

Glucagon infusion. Crystalline beef and pork glucagon (Eli Lilly and Co., Indianapolis, Ind.) was administered as a continuous infusion via a peristaltic pump (Extracorporeal Medical Specialties, Inc., King of Prussia, Pa.) to 21 normal and 10 uremic subjects. Before administration, the glucagon was initially diluted in sterile, pyrogen-free water containing $300 \mathrm{mg} / 100 \mathrm{ml}$ of human serum albumin (Armour Pharmaceutical Co., Chicago, Ill.). This solution was further diluted with physiological saline and an aliquot of the subject's whole blood ( $4 \mathrm{ml}$ of whole blood per $100 \mathrm{ml}$ of infusate, to prevent adherence of the glucagon to glassware or tubing) so as to achieve a final glucagon concentration in the infusate of $500 \mathrm{ng} / \mathrm{ml}$. The continuous infusion dose was $3 \mathrm{ng} / \mathrm{kg}$ body weight per min, administered for 150-180 min. In eight additional healthy controls, glucagon was infused at a dose of $6 \mathrm{ng} / \mathrm{kg}$ body weight per min. Blood samples were obtained at 15-30 min intervals during the infusion.

\section{Analyses and calculations}

Glucose was measured by the glucose oxidase technique (17). The methods employed for the determination of plasma immunoreactive insulin, plasma immunoreactive glucagon (using Unger antibody $30 \mathrm{~K}$ ), and plasma acidic and neutral amino acids have been described previously (18).

The metabolic clearance rate of glucagon $\left(\mathrm{MCR}_{G}\right),{ }^{1}$ the volume of plasma completely and irreversibly cleared of glucagon per minute, was calculated according to the formula (19) :

$\mathrm{MCR}_{\mathbf{G}}=$ Glucagon infused per minute Glucagon concentration at equilibrium - basal concentration

${ }^{1}$ Abbreviations used in this paper: $\mathrm{BSDR}_{\mathrm{G}}$, basal systemic delivery rate of glucagon; $M_{C} R_{G}$, metabolic clearance rate of glucagon. 


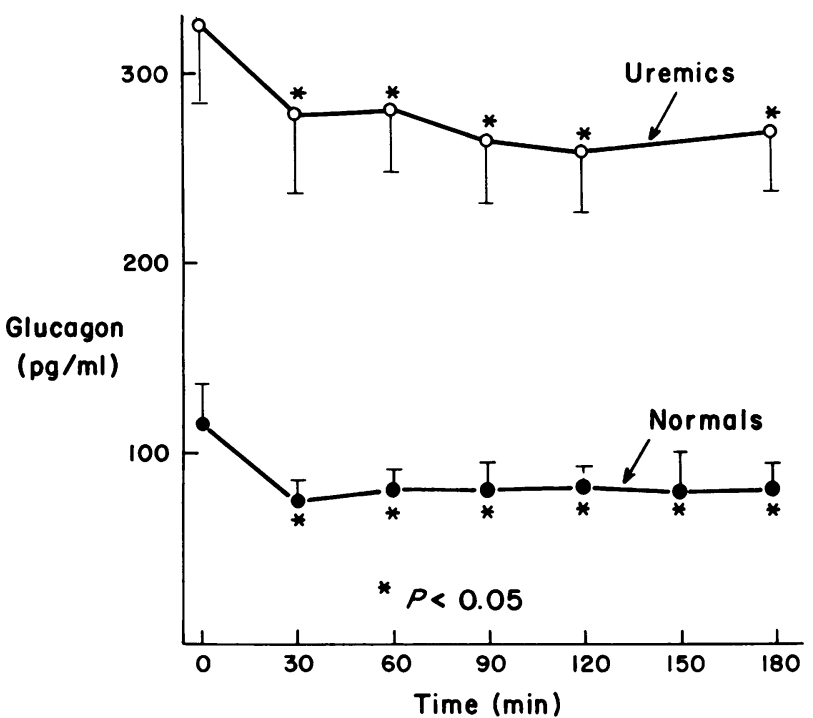

Figure 1 Plasma glucagon levels in the basal state and after the oral administration of $100 \mathrm{~g}$ of glucose to normal and uremic subjects. $P$ values refer to the significance of the changes from the basal state ( 0 time) within each group. Despite the fall in plasma glucagon induced by glucose in the uremic group, glucagon concentrations remained significantly higher in the uremic group than in controls throughout the period of study $(P<0.001)$. No differences were noted with respect to dialyzed vs. nondialyzed uremics; the data for both uremic groups are consequently combined in the figure.

In this calculation it was assumed that: $(a)$ endogenous glucagon secretion remains at basal levels throughout each study; $(b)$ exogenous beef and pork glucagon turnover is indistinguishable from that of endogenous origin; and (c) glucagon removal is linear over the range of concentrations studied. Recent studies from our laboratory in normal man have, in fact, shown that glucagon removal is linear over a wide range of physiological concentrations (including levels similar to those observed in uremia). ${ }^{2}$ In addition, ingestion of glucose during a continuous infusion of exogenous glucagon results in a significant decline in plasmaglucagon concentration (as compared to subjects receiving glucagon alone), thus suggesting continued basal secretion of endogenous glucagon during the infusion of exogenous hormone (20). The basal systemic delivery rate of glucagon $\left(B S D R_{G}\right)$, the quantity of endogenous glucagon released into the systemic circulation each minute, is calculated as the product of the basal plasma glucagon concentration and $\mathbf{M C R}_{\boldsymbol{G}}$ (19). The term BSDR $_{\boldsymbol{G}}$ was chosen since our calculations exclude that portion of total splanchnic glucagon secretion removed by the liver before entering the general circulation.

Statistical analyses were performed with the Student's $t$ test (the paired $t$ test was used when applicable), linear regression analysis, and analysis of variance (21). Data in the text are presented as the mean $\pm \mathrm{SE}$.

${ }^{2}$ Fisher, M., R. S. Sherwin, R. Hendler, and P. Felig. The kinetics of glucagon in man: Effects of starvation. In preparation.

\section{RESULTS}

Glucagon concentrations in the basal state and after glucose and alanine administration. In accordance with the observations of Bilbrey et al. (14), the postabsorptive glucagon concentration was increased fourfold in uremic patients $(349 \pm 32 \mathrm{pg} / \mathrm{ml})$ as compared to controls $(90 \pm 8 \mathrm{pg} / \mathrm{ml}, P<0.001)$. Basal glucagon levels in uremics were not significantly different in dialyzed $(326 \pm 34 \mathrm{pg} / \mathrm{ml})$ or undialyzed patients $(384 \pm 65 \mathrm{pg} /$ $\mathrm{ml}$ ). Hyperglucagonemia was also observed in the uremic group after glucose (Fig. 1) or alanine administration (Fig. 2). After glucose ingestion, glucagon concentration in the uremics fell by $20-25 \%$ below postabsorptive levels; however, the postglucose values in the uremics remained three- to fourfold greater than in the controls (Fig. 1). After intravenous alanine, plasma glucagon concentration increased in both normal and uremic subjects (Fig. 2). The mean maximal glucagon increment $(401 \pm 135 \mathrm{pg} / \mathrm{ml})$ and the area under the glucagon-response curve $(15,880 \pm 4,875 \mathrm{pg} / \mathrm{ml} \times \min )$ were three- to fourfold greater than in the controls $(106 \pm 13 \mathrm{pg} / \mathrm{ml}[P<0.05]$, and $4,581 \pm 639 \mathrm{pg} / \mathrm{ml} \times$ $\min [P<0.05]$, respectively). More striking, however, was the persistence of the glucagon response in the uremics. Glucagon increments $50 \mathrm{~min}$ after alanine were markedly increased in the uremics $(221 \pm 66 \mathrm{pg} / \mathrm{ml}$ vs.

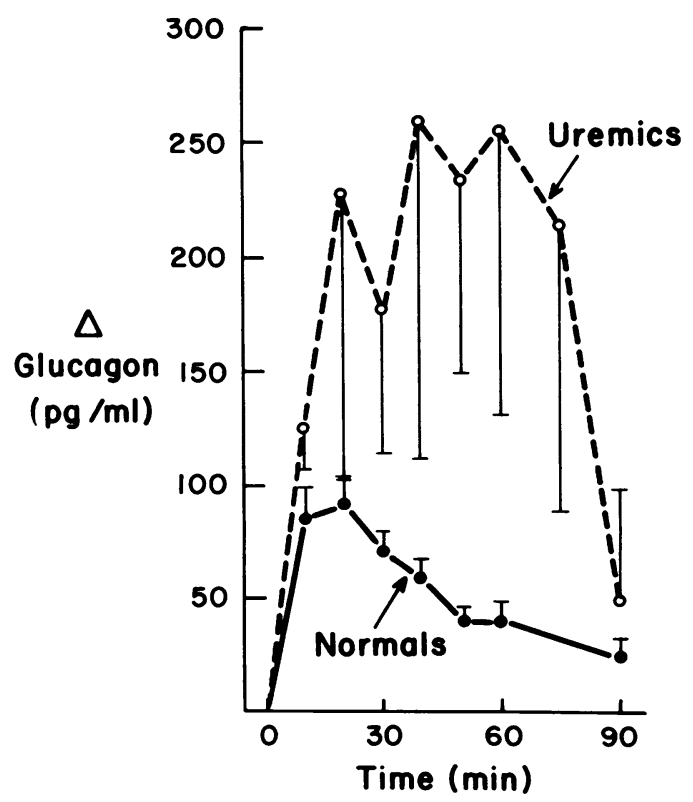

FIGURE 2 Changes in plasma glucagon after the infusion of alanine $(0.15 \mathrm{~g} / \mathrm{kg})$ in normal and uremic subjects. Glucagon levels were significantly greater in the uremic group at $50 \mathrm{~min}(P<0.02)$ and at $60 \mathrm{~min}(P<0.05)$. No differences were noted with respect to dialyzed vs. nondialyzed uremics; the data for both uremic groups are consequently combined in the figure. 


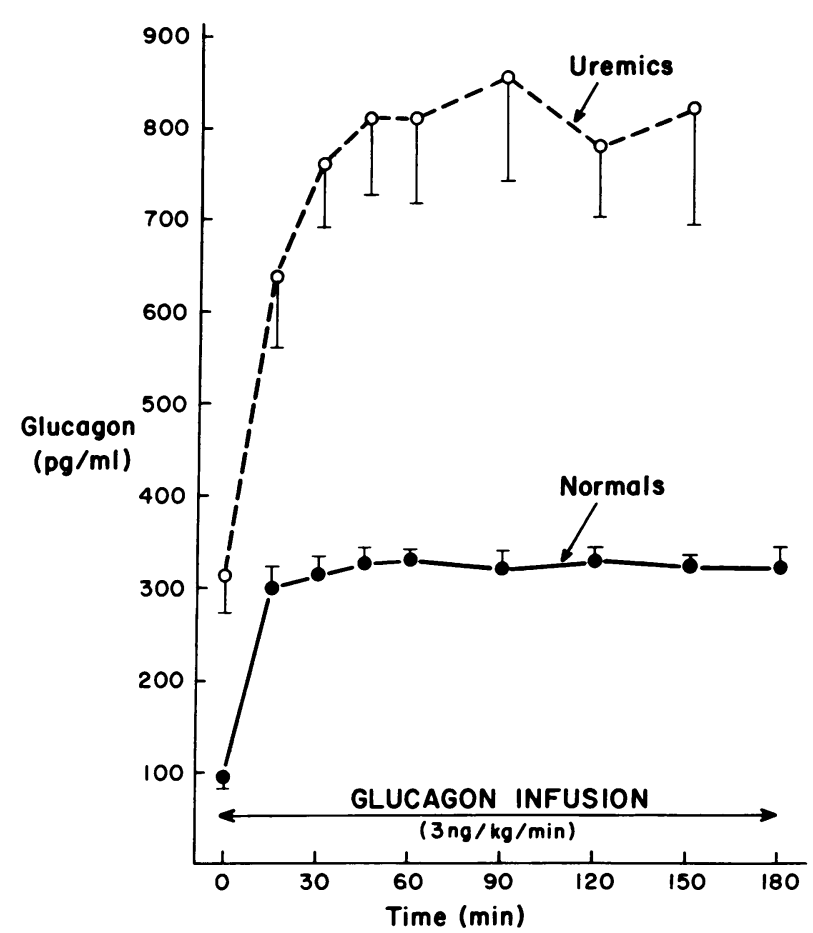

FIGURE 3 Plasma glucagon concentrations during the infusion of exogenous glucagon ( $3 \mathrm{ng} / \mathrm{kg}$ per $\mathrm{min}$ ) to normal and uremic subjects. The response was the same in nondialyzed and dialyzed uremics; the data for both uremic groups are consequently combined in the figure.

$40 \pm 7 \mathrm{pg} / \mathrm{ml}$ in controls, $P<0.02)$. The prolonged elevation of plasma glucagon is compatible with decreased hormone turnover in uremia. The plasma glucagon responses to glucose and alanine administration were not significantly different in the dialyzed as compared to the undialyzed patients.

Glucagon kinetics in uremic and normal subjects. The continuous infusion of glucagon in the control and uremic patients resulted in stable plasma glucagon concentrations after $15-45 \mathrm{~min}$ (Fig. 3). However, the increment in glucagon in the uremic group (581 \pm 48 pg) was two- to threefold greater than in controls (233 $\pm 13 \mathrm{pg} / \mathrm{ml}, P<0.001)$. Furthermore, the time required to reach a stable plateau after glucagon administration was longer in the uremics $(45 \mathrm{~min})$ than in controls (15 min), thus suggesting decreased hormone degradation. The calculated $\mathrm{MCR}_{\mathrm{G}}$ was $5.8 \pm 0.6 \mathrm{ml} / \mathrm{kg}$ per min in the uremics, which is $58 \%$ below that observed in controls $(13.8 \pm 0.9 \mathrm{ml} / \mathrm{kg}$ per $\min P<0.001)$. In contrast, the $\mathrm{BSDR}_{\boldsymbol{a}}$ was not significantly different in uremic patients $(1.78 \pm 0.20 \mathrm{ng} / \mathrm{kg}$ per $\mathrm{min})$ as compared to healthy controls $(1.34 \pm 0.17 \mathrm{ng} / \mathrm{kg}$ per $\mathrm{min}$, $P>0.1)$. Chronic dialysis had no effect on the increment in plasma glucagon induced by the glucagon infusion $(569 \pm 41 \mathrm{pg} / \mathrm{ml}$ in the dialyzed group and 593 \pm 93 in the undialyzed group), nor did it affect the calculated $\mathrm{MCR}_{\mathbf{G}}(5.9 \pm 0.4 \mathrm{ml} / \mathrm{kg}$ per min in dialyzed uremics and $5.8 \pm 1.3$ in undialyzed uremics). Similarly, $\mathrm{BSDR}_{\mathbf{G}}$ was not significantly different in dialyzed $(2.03$ $\pm 0.34 \mathrm{ng} / \mathrm{kg}$ per $\mathrm{min})$ and undialyzed uremics (1.53 $\pm 0.21 \mathrm{ng} / \mathrm{kg}$ per $\min , P>0.1$ ).

Glucose and insulin concentrations in the basal state and in response to glucose ingestion. The postabsorptive glucose concentration was increased in the uremic patients $(93 \pm 4 \mathrm{mg} / 100 \mathrm{ml})$ as compared to controls $(78 \pm 1 \mathrm{mg} / 100 \mathrm{ml}, P<0.001)$. Basal glucose concentration was not significantly different in dialyzed (89 $\pm 4 \mathrm{mg} / 100 \mathrm{ml}$ ) and undialyzed $(96 \pm 5 \mathrm{mg} / 100 \mathrm{ml})$ uremics. Similarly, postabsorptive insulin concentration was increased in uremic patients $(24 \pm 3$ vs. $14 \pm 1 \mu \mathrm{U} /$ $\mathrm{ml}$ in controls, $P<0.005)$. However, when uremic patients were subdivided into undialyzed $(30 \pm 6 \mu \mathrm{U} / \mathrm{ml}$ ) and dialyzed $(19 \pm 3 \mu \mathrm{U} / \mathrm{ml})$ subjects, only the undialyzed uremics demonstrated significant basal hyperinsulinemia $(P<0.02)$.

After oral glucose administration, the plasma glucose concentration was significantly increased in the uremic group as compared to healthy controls (Fig. 4A). When uremics were subdivided on the basis of dialysis, undialyzed uremics demonstrated significantly increased glucose values when compared to dialyzed uremics (Fig. 4B). The improved glucose tolerance in the dialyzed group is also indicated by the fact that the glucose values in this group differed significantly from the control subjects only at 120 and $180 \mathrm{~min}(P<0.05)$ (Fig. 4B). Plasma insulin concentrations after glucose ingestion closely paralleled the glucose response. Uremic patients demonstrated significantly increased insulin levels when compared to controls (Fig. 4C). However, whereas the glucose-stimulated insulin response was 2- to 10 fold above control levels in the undialyzed uremic group throughout the 3-h study, the dialyzed uremics showed only a delayed, 2- to 3-fold increment in insulin (Fig. 4D).

Glucose and insulin responses to intravenous alanine. After alanine administration, the mean maximal increments in glucose and insulin for the uremic group as a whole $(7 \pm 2 \mathrm{mg} / 100$ and $27 \pm 7 \mu \mathrm{U} / \mathrm{ml}$, respectively), were not significantly different from normal subjects $(6 \pm 1 \mathrm{mg} / 100 \mathrm{ml}$ and $15 \pm 2 \mu \mathrm{U} / \mathrm{ml}$, respectively). However, when uremics were subdivided according to dialysis, the mean maximal increments in glucose in the undialyzed uremics $(12 \pm 3 \mathrm{mg} / 100 \mathrm{ml})$ tended to be greater than in controls $(6 \pm 1 \mathrm{mg} / 100 \mathrm{ml}, P<0.1)$ or in dialyzed uremics $(3 \pm 1 \mathrm{mg} / 100 \mathrm{ml}, P<0.05)$. Similarly, the mean maximal increment in insulin in the undialyzed uremics $(43 \pm 12 \mu \mathrm{U} / \mathrm{ml})$ was significantly greater than in controls $(15 \pm 2 \mu \mathrm{U} / \mathrm{ml}, P<0.05)$, or in dialyzed uremics $(11 \pm 2 \mu \mathrm{U} / \mathrm{ml}, P<0.05)$. 

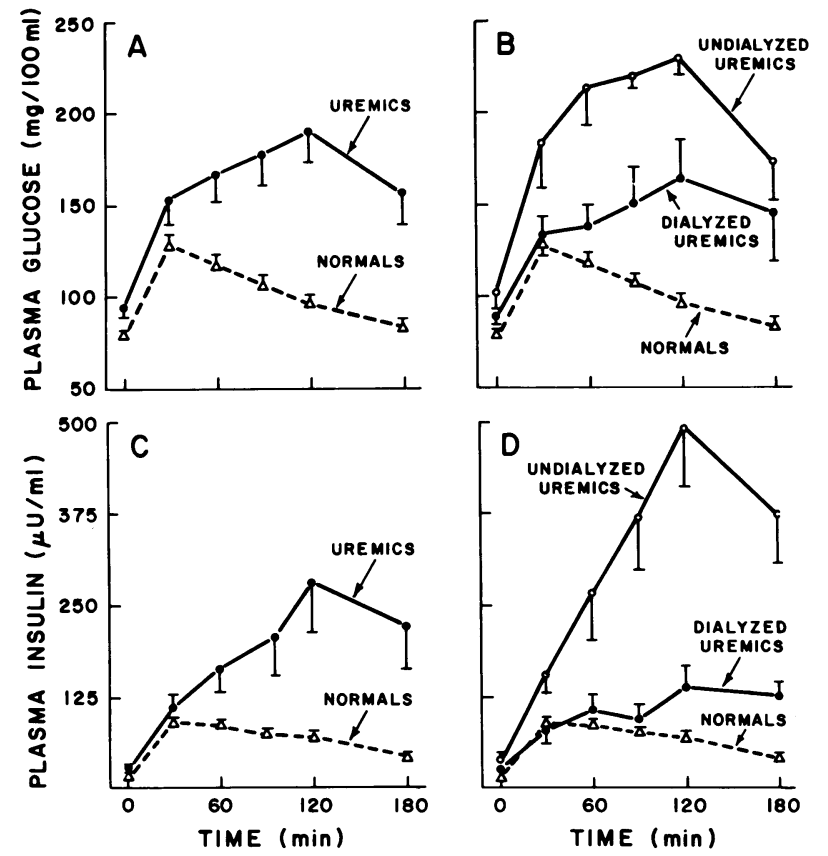

FIgURE 4 Plasma glucose and insulin response to ingestion of $100 \mathrm{~g}$ glucose in normal and uremic subjects. In panels $\mathrm{A}$ and $\mathrm{C}$, the responses of the dialyzed $(n=6)$ and undialyzed $(n=4)$ uremics are combined, while in panels B and $D$ the two uremic groups are shown separately. The glucose response of the undialyzed uremics was significantly greater than the dialyzed group at $60(P<0.02), 90(P<$ $0.01)$, and $120 \mathrm{~min}(P<0.05)$. Similarly, the insulin response in the undialyzed uremics was greater than in the dialyzed group at $30(P<0.02), 60(P<0.05), 90(P<$ $0.005), 120(P<0.005)$, and $180 \mathrm{~min}(P<0.02)$.

Glucose and insulin response to glucagon administration. The increment in plasma glucose concentration after intravenous glucagon infusion was two- to fourfold greater in the uremics as a whole, as compared to controls (Fig. 5A). However, when the effect of dialysis on glucagon-induced hyperglycemia was examined, the undialyzed uremics account for the differences observed. Despite comparable increments in plasma glucagon in the dialyzed and undialyzed subjects (see above), the glucose response to glucagon was increased above control levels only in the undialyzed uremics (Fig. 5B). The mean maximal glucose increment in undialyzed uremics $(37 \pm 9 \mathrm{mg} / 100 \mathrm{ml})$ was three- to fourfold greater than in dialyzed uremics $(10 \pm 1 \mathrm{mg} /$ $100 \mathrm{ml}, P<0.02)$ or controls $(10 \pm 1 \mathrm{mg} / 100 \mathrm{ml}, P$ $<0.02)$. Furthermore, the area under the glucoseresponse curve in the undialyzed uremics $(2,922 \pm 882$ $\mathrm{mg} / 100 \mathrm{ml} \times \mathrm{min}$ ) was significantly increased when compared to dialyzed uremics $(730 \pm 215 \mathrm{mg} / 100 \mathrm{ml}$ $\times \min , P<0.05)$ or controls $(577 \pm 150 \mathrm{mg} / 100 \mathrm{ml}$ $\times \min , P<0.02$ ). For the entire uremic group, a significant direct linear correlation was observed between the maximal glucose response to glucagon administration and the 2-h plasma glucose concentration during the oral glucose tolerance test $(r=0.82, P<0.05)$.

Changes in plasma insulin after glucagon administration were similar to those demonstrated for glucose. Increases in the plasma insulin response to glucagon in uremic subjects were accounted for by hyperinsulinemia in the undialyzed group only (Fig. 5C and D). Mean maximal insulin increments in undialyzed uremics ( 27 $\pm 6 \mu \mathrm{U} / \mathrm{ml})$ exceeded those of controls $(9 \pm 1 \mu \mathrm{U} / \mathrm{ml}$, $P<0.01)$ and dialyzed uremics $(5 \pm 1 \mu \mathrm{U} / \mathrm{ml}, P<$ 0.01 ).

In addition to the $3 \mathrm{ng} / \mathrm{kg}$ per min infusion of glucagon, the healthy control subjects received infusions
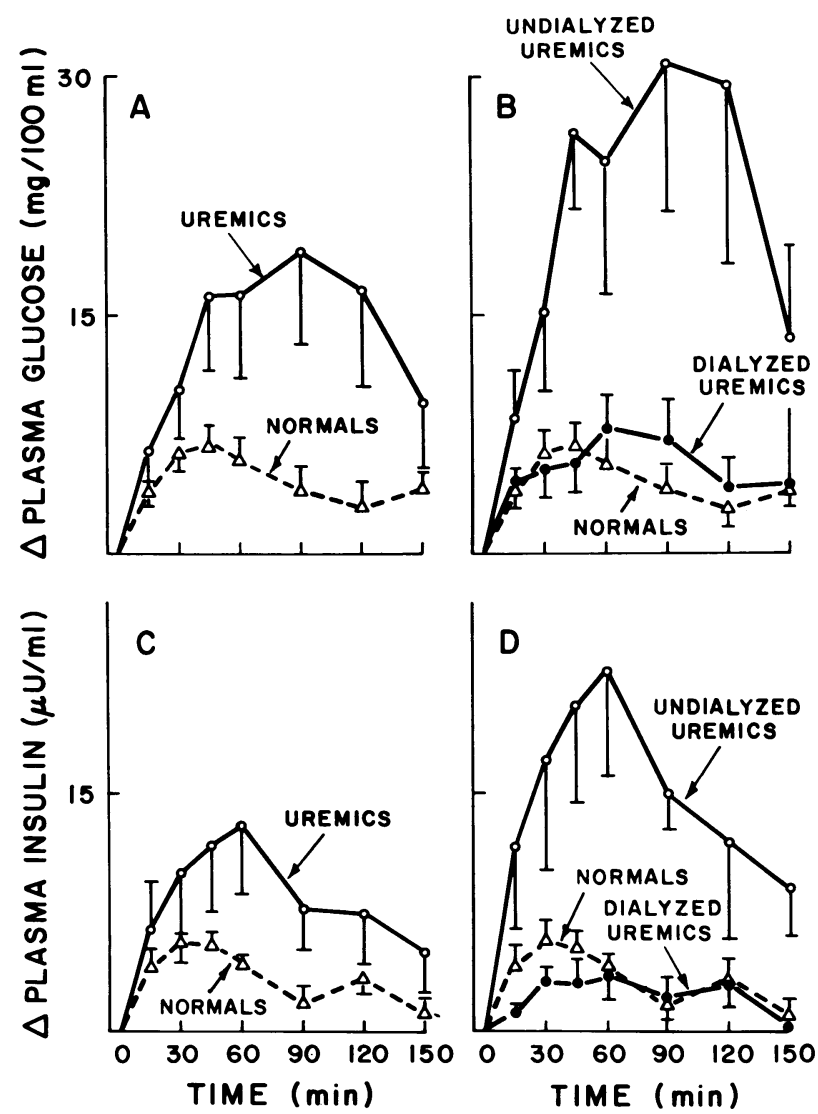

FIGURE 5 Changes in plasma glucose and insulin in response to the infusion of glucagon $(3 \mathrm{ng} / \mathrm{kg}$ per $\mathrm{min}$ ) in normal and uremic subjects. In panels $A$ and $C$, the responses of the dialyzed $(n=5)$ and undialyzed $(n=5)$ uremics are combined, while in panels $B$ and $D$, the two uremic groups are shown separately. The increments in plasma glucose were greater in the undialyzed uremics than in the dialyzed uremics or healthy controls at $45 \quad(P<$ $0.005), 60(P<0.05), 90(P<0.05)$, and $120 \mathrm{~min}(P<$ $0.05)$. Similarly, the insulin response was greater in undialyzed uremics than in dialyzed uremics or normal controls at $45(P<0.02), 60(P<0.02), 90(P<0.01)$, and $150 \min (P<0.02)$. 
at a rate of $6 \mathrm{ng} / \mathrm{kg}$ per min. This rate of infusion resulted in increments in plasma glucagon in the normal group which were equivalent to those observed in uremics during the $3 \mathrm{ng} / \mathrm{kg}$ per min infusion (Fig. 6). Despite comparable hyperglucagonemia, the glucose rise in the undialyzed uremics exceeded that of healthy controls (Fig. 6). The mean maximal glucose increment in the control subjects receiving the $6 \mathrm{ng} / \mathrm{kg}$ per min glucagon infusion $(16 \pm 3 \mathrm{mg} / 100 \mathrm{ml})$ was less than half that observed in the undialyzed uremic group receiving the $3 \mathrm{ng} / \mathrm{kg}$ per min infusion $(37 \pm 9 \mathrm{mg} / 100$ $\mathrm{ml}, P<0.05)$. The maximal insulin increment in the controls during the $6 \mathrm{ng} / \mathrm{kg}$ per min infusion $(12 \pm 3$ $\mu \mathrm{U} / \mathrm{ml}$ ) was significantly below that observed in the undialyzed uremics during the $3 \mathrm{ng} / \mathrm{kg}$ per min infusion $(27 \pm 6, P<0.05)$.

Plasma amino acids in the basal state and after glucagon administration. Plasma amino acid concentrations in the basal state and the changes observed after glucagon infusion are shown in Table I. Uremic subjects demonstrated threefold increases in basal levels of citrulline and cystine $(P<0.001)$, as well as elevated taurine $(P<0.05)$, glycine $(P<0.01)$, and proline $(P<$ $0.001)$ concentrations. Basal valine $(P<0.005)$, tyrosine $(P<0.02)$, and $\alpha$-aminobutyrate $(P<0.05)$ concentrations were significantly reduced. No differences were observed between dialyzed and undialyzed subjects except in the case of glycine. Glycine concentration in the dialyzed group $(548 \pm 90 \mu \mathrm{mol} / \mathrm{liter})$ was twice that observed in the undialyzed group $(249 \pm 18, P<0.01)$ or in normal controls $(207 \pm 16, P<0.005)$.
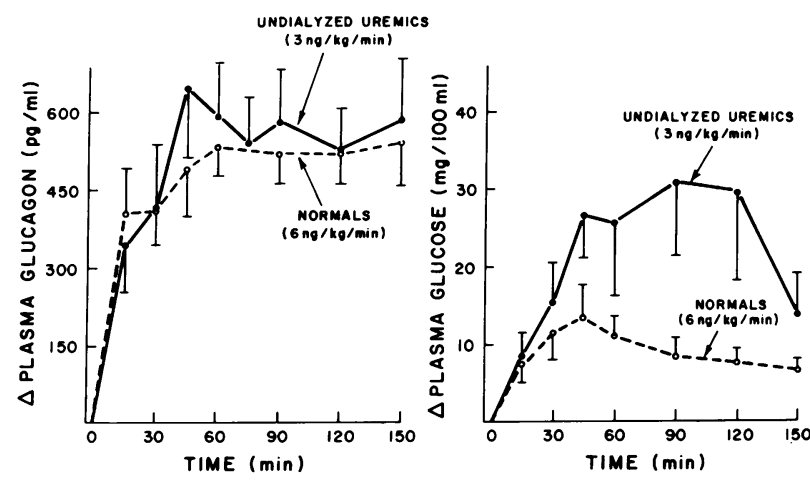

FIGURE 6 Changes in plasma glucagon and glucose in undialyzed uremics and in normal controls during the infusion of glucagon at rates causing equivalent increases in plasma glucagon. Glucagon was infused at a rate of $3 \mathrm{ng} / \mathrm{kg}$ per min in the uremics $(n=5)$ and at a rate of $6 \mathrm{ng} / \mathrm{kg}$ per $\min$ in the normal controls $(n=8)$. The glucose response over the course of the study was significantly greater in the uremics as compared to controls $(P<0.02$, analysis of variance). In addition, the mean maximal increment in glucose in the uremics $(37 \pm 9 \mathrm{mg} / 100 \mathrm{ml})$ was significantly greater than in controls $(16 \pm 3 \mathrm{mg} / 100 \mathrm{ml}, P<0.05)$.
The glucagon infusion ( $3 \mathrm{ng} / \mathrm{kg}$ per $\mathrm{min}$ ) failed to produce any consistent changes in plasma amino acid concentrations in the normal control group, except for a $7 \%$ decline in serine (Table I). In contrast, a significant fall in virtually all amino acids was demonstrable in the uremic group (Table I). The magnitude of the decrease in alanine $(24 \pm 2 \%)$ exceeded that of all other amino acids. The amino acid response to glucagon was the same in dialyzed and undialyzed uremic patients. When the glucagon infusion rate was increased to $6 \mathrm{ng} / \mathrm{kg}$ per min in normals to achieve increments in plasma glucagon comparable to the uremics (Fig. 6), plasma alanine concentration still failed to decline in the normal group (Fig. 7). With the exception of small $(10-19 \%)$ reductions in glycine, serine, and threonine, the other amino acids were also unchanged by the high-dose glucagon infusion.

\section{DISCUSSION}

The current data demonstrate that chronic renal failure is associated with hyperglucagonemia in the basal state, after glucose suppression, and after alanine stimulation. Similar results have been previously reported with respect to basal and postglucose values (14). Bilbrey et al., however, failed to observe augmented glucagon levels after protein ingestion (14). Whether the differences observed between protein ingestion and intravenous alanine are related to altered protein absorption in uremia (22), or are due to the different nature of the aminogenic stimulus remains to be determined. The present findings extend previous observations, $(a)$ by providing data on the relative contributions of altered hormone catabolism and secretion to increased plasma glucagon levels in uremia, and $(b)$ by evaluating the effects of uremia and dialysis on the glycemic and amino acid responses to physiological increments in plasma glucagon.

In the uremic group, the $\mathrm{MCR}_{\mathrm{G}}$ was decreased by $58 \%$ as compared to healthy subjects. In contrast, the $\mathrm{BSDR}_{\mathbf{G}}$ was unchanged from controls. These data thus suggest that hyperglucagonemia in uremia is a consequence of decreased hormonal catabolism rather than hypersecretion. The techniques employed in the current study cannot exclude the possibility of increased hepatic extraction of glucagon and associated hypersecretion in the uremic group. However, previous observations in intact man have demonstrated a portal-peripheral gradient for glucagon which is no greater than $1.3: 1$, indicating that the liver is a minor site of glucagon degradation (23). Thus, the comparable BSDR in $_{\mathbf{a}}$ in uremic and normal subjects are likely to be a close approximation of the true pancreatic secretory rates.

It should be noted that the calculations employed in determining $\mathrm{MCR}_{\mathbf{G}}$ assume ongoing secretion of en- 
TABLE I

Plasma Concentrations of Amino Acids during Intravenous Infusion of Glucagon (3 $\mathrm{ng} / \mathrm{kg}$ body weight per min) in Normal and Uremic Subjects*

\begin{tabular}{|c|c|c|c|c|c|c|}
\hline Amino acid & Condition & 0 & $30 \mathrm{~min}$ & $60 \mathrm{~min}$ & $120 \mathrm{~min}$ & $150-180 \mathrm{~min} \ddagger$ \\
\hline Taurine & $\begin{array}{l}\mathrm{N} \S \\
\mathrm{U} \|\end{array}$ & $\begin{array}{l}33 \pm 2 \\
49 \pm 6\end{array}$ & $\begin{array}{l}32 \pm 2 \\
46 \pm 6\end{array}$ & $\begin{array}{l}33 \pm 2 \\
45 \pm 7\end{array}$ & $\begin{array}{l}31 \pm 2 \\
47 \pm 7\end{array}$ & $\begin{array}{l}30 \pm 2 \\
43 \pm 79\end{array}$ \\
\hline Threorine & $\begin{array}{l}\mathrm{N} \\
\mathrm{U}\end{array}$ & $\begin{array}{l}109 \pm 6 \\
132 \pm 14\end{array}$ & $\begin{array}{l}111 \pm 7 \\
132 \pm 17\end{array}$ & $\begin{array}{l}110 \pm 7 \\
117 \pm 169\end{array}$ & $\begin{array}{l}109 \pm 8 \\
114 \pm 169\end{array}$ & $\begin{array}{l}104 \pm 7 \\
106 \pm 14^{* *}\end{array}$ \\
\hline Serine & $\begin{array}{l}\mathrm{N} \\
\mathrm{U}\end{array}$ & $\begin{array}{l}101 \pm 4 \\
100 \pm 12\end{array}$ & $\begin{array}{c}101 \pm 4 \\
87 \pm 12\end{array}$ & $\begin{array}{c}101 \pm 5 \\
83 \pm 9 ף\end{array}$ & $\begin{array}{l}99 \pm 5 \\
87 \pm 11 \text { ฯ }\end{array}$ & $\begin{array}{l}94 \pm 5 \rrbracket \\
80 \pm 14^{* *}\end{array}$ \\
\hline Proline & $\begin{array}{l}\mathrm{N} \\
\mathrm{U}\end{array}$ & $\begin{array}{l}158 \pm 16 \\
285 \pm 11\end{array}$ & $\begin{array}{l}161 \pm 15 \\
282 \pm 15\end{array}$ & $\begin{array}{l}158 \pm 15 \\
264 \pm 16\end{array}$ & $\begin{array}{l}155 \pm 16 \\
261 \pm 16 ף\end{array}$ & $\begin{array}{l}146 \pm 14 \\
251 \pm 17 ף\end{array}$ \\
\hline Citrulline & $\begin{array}{l}\mathrm{N} \\
\mathrm{U}\end{array}$ & $\begin{array}{l}29 \pm 5 \\
86 \pm 11\end{array}$ & $\begin{array}{l}29 \pm 4 \\
84 \pm 13\end{array}$ & $\begin{array}{l}29 \pm 5 \\
83 \pm 13\end{array}$ & $\begin{array}{l}26 \pm 4 \\
83 \pm 13\end{array}$ & $\begin{array}{l}23 \pm 2 \\
74 \pm 10^{* *}\end{array}$ \\
\hline Glycine & $\begin{array}{l}\mathrm{N} \\
\mathrm{U}\end{array}$ & $\begin{array}{l}207 \pm 16 \\
399 \pm 65\end{array}$ & $\begin{array}{l}209 \pm 17 \\
386 \pm 72\end{array}$ & $\begin{array}{l}210 \pm 17 \\
353 \pm 61^{* *}\end{array}$ & $\begin{array}{l}207 \pm 16 \\
365 \pm 609\end{array}$ & $\begin{array}{l}204 \pm 16 \\
336 \pm 59 \ddagger \ddagger\end{array}$ \\
\hline Alanine & $\begin{array}{l}\mathrm{N} \\
\mathrm{U}\end{array}$ & $\begin{array}{l}295 \pm 22 \\
309 \pm 25\end{array}$ & $\begin{array}{l}307 \pm 31 \\
295 \pm 31\end{array}$ & $\begin{array}{l}307 \pm 29 \\
280 \pm 23\end{array}$ & $\begin{array}{l}306 \pm 27 \\
270 \pm 24 \uparrow\end{array}$ & $\begin{array}{l}294 \pm 22 \\
237 \pm 21 \ddagger \ddagger\end{array}$ \\
\hline$\alpha$-Amniobutyrate & $\begin{array}{l}\mathrm{N} \\
\mathrm{U}\end{array}$ & $\begin{array}{r}16 \pm 2 \\
8 \pm 3\end{array}$ & $\begin{array}{r}18 \pm 2 \\
8 \pm 3\end{array}$ & $\begin{array}{r}16 \pm 2 \\
7 \pm 2\end{array}$ & $\begin{array}{r}16 \pm 2 \\
8 \pm 3\end{array}$ & $\begin{array}{r}15 \pm 2 \\
8 \pm 3\end{array}$ \\
\hline Valine & $\begin{array}{l}\mathrm{N} \\
\mathrm{U}\end{array}$ & $\begin{array}{l}203 \pm 11 \\
150 \pm 12\end{array}$ & $\begin{array}{l}206 \pm 12 \\
151 \pm 13\end{array}$ & $\begin{array}{l}200 \pm 12 \\
141 \pm 10\end{array}$ & $\begin{array}{l}196 \pm 12 \\
133 \pm 129\end{array}$ & $\begin{array}{l}190 \pm 11 \\
127 \pm 13 \ddagger \ddagger\end{array}$ \\
\hline Cystine & $\begin{array}{l}\mathrm{N} \\
\mathrm{U}\end{array}$ & $\begin{array}{r}99 \pm 12 \\
283 \pm 27\end{array}$ & $\begin{array}{r}94 \pm 19 \\
283 \pm 23\end{array}$ & $\begin{array}{r}91 \pm 16 \\
278 \pm 29\end{array}$ & $\begin{array}{c}87 \pm 14^{* *} \\
267 \pm 28\end{array}$ & $\begin{array}{c}99 \pm 9 \\
254 \pm 25\end{array}$ \\
\hline Methionine & $\begin{array}{l}\mathrm{N} \\
\mathrm{U}\end{array}$ & $\begin{array}{l}28 \pm 1 \\
26 \pm 3\end{array}$ & $\begin{array}{l}27 \pm 2 \\
25 \pm 3\end{array}$ & $\begin{array}{l}28 \pm 2 \\
22 \pm 2\end{array}$ & $\begin{array}{l}29 \pm 1 \\
20 \pm 2\end{array}$ & $\begin{array}{l}30 \pm 1 \\
19 \pm 3\end{array}$ \\
\hline Isoleucine & $\begin{array}{l}\mathrm{N} \\
\mathrm{U}\end{array}$ & $\begin{array}{l}60 \pm 3 \\
56 \pm 5\end{array}$ & $\begin{array}{l}59 \pm 4 \\
59 \pm 6\end{array}$ & $\begin{array}{l}58 \pm 3 \\
53 \pm 6\end{array}$ & $\begin{array}{l}54 \pm 5 \\
50 \pm 7\end{array}$ & $\begin{array}{l}55 \pm 4 \\
44 \pm 6 \ddagger \ddagger\end{array}$ \\
\hline Leucine & $\begin{array}{l}\mathrm{N} \\
\mathrm{U}\end{array}$ & $\begin{array}{r}112 \pm 7 \\
90 \pm 9\end{array}$ & $\begin{array}{r}111 \pm 8 \\
87 \pm 9\end{array}$ & $\begin{array}{r}109 \pm 8 \\
81 \pm 7\end{array}$ & $\begin{array}{r}105 \pm 10 \\
78 \pm 8 \Phi\end{array}$ & $\begin{array}{c}106 \pm 9 \\
75 \pm 10^{* *}\end{array}$ \\
\hline Tyrosine & $\begin{array}{l}\mathrm{N} \\
\mathrm{U}\end{array}$ & $\begin{array}{l}45 \pm 3 \\
33 \pm 3\end{array}$ & $\begin{array}{l}44 \pm 3 \\
32 \pm 3\end{array}$ & $\begin{array}{l}44 \pm 3 \\
29 \pm 2\end{array}$ & $\begin{array}{l}46 \pm 3 \\
26 \pm 29\end{array}$ & $\begin{array}{l}43 \pm 2 \\
26 \pm 3^{* *}\end{array}$ \\
\hline Phenylalanine & $\begin{array}{l}\mathrm{N} \\
\mathrm{U}\end{array}$ & $\begin{array}{l}49 \pm 3 \\
55 \pm 5\end{array}$ & $\begin{array}{l}48 \pm 3 \\
56 \pm 6\end{array}$ & $\begin{array}{l}48 \pm 3 \\
50 \pm 5\end{array}$ & $\begin{array}{l}48 \pm 3 \\
47 \pm 4 ף\end{array}$ & $\begin{array}{l}46 \pm 2 \\
44 \pm 5 \ddagger t\end{array}$ \\
\hline
\end{tabular}

* Data presented as mean \pm SE. $P$ values refer to significance of difference from preinfusion values (paired $t$ ).

$\ddagger$ Indicates that amino acids were measured at $150 \mathrm{~min}$ in uremics and $180 \mathrm{~min}$ in normal subjects.

$\S$ Indicates normal subjects $(n=10)$.

II Indicates uremic subjects $(n=10)$.

II Indicates $P<0.05$.

** Indicates $P<0.01$.

¥¥ Indicates $P<0.001$.

dogenous glucagon. This assumption is based on indirect evidence in normal subjects infused with glucagon followed by glucose (20). If this assumption were not valid, the values for $M C R_{G}$ would be lower both in the controls $(9.5 \pm 0.4 \mathrm{ml} / \mathrm{kg}$ per $\min )$ and the uremics $(3.6 \pm 0.4)$. However, the significant differences between these groups $(P<0.001)$ would not be appreciably altered. On the other hand, if one assumes that endogenous glucagon secretion is suppressed in controls but not in uremics, the metabolic clearance rate in the uremics remains significantly reduced when compared to controls $(P<0.001)$.

The demonstration that hyperglucagonemia in uremia is associated with decreased hormonal catabolism strongly implicates the kidney as a principal site of glucagon degradation. As noted above, the small portal- 


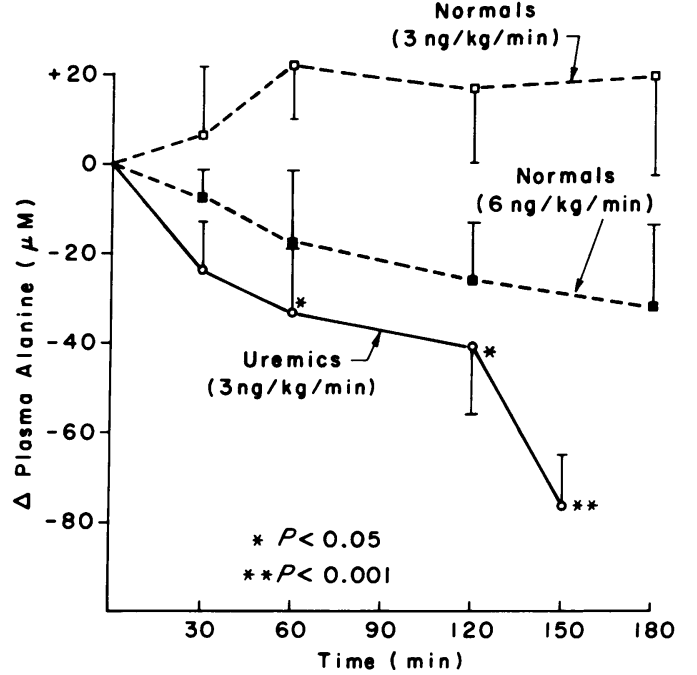

Figure 7 Changes in plasma alanine in response to the infusion of glucagon in uremic and normal subjects. The normal subjects were studied during the infusion of glucagon at rates of 3 and $6 \mathrm{ng} / \mathrm{kg}$ per min. The infusion rate in the uremics was $3 \mathrm{ng} / \mathrm{kg}$ per min. The alanine response in dialyzed and undialyzed uremics was the same, consequently the data for the two uremic groups are combined in the figure. $P$ values refer to the significance of the changes from the basal concentration. In the normal subjects (at both infusion rates) there were no significant changes in alanine levels during the infusion.

peripheral gradient for glucagon $(23,24)$ is compatible with an extrahepatic degradative site. Glucagon degradative enzymes have, in fact, recently been demonstrated in kidney tissue (25). Consistent renal extraction of glucagon has been observed in the autotransplanted dog kidney (26). Recent studies in our laboratory reveal a fractional extraction ratio of glucagon across the kidney in the intact dog and rat of $40 \% .^{3}$ After the induction of renal failure by $75 \%$ nephrectomy, a consistent renal uptake of glucagon is no longer observed. ${ }^{3}$ Furthermore, renal artery clamping (27) and ureteral ligation (14) in dogs result in a rapid rise in plasma glucagon. In contrast, a decrease in circulating glucagon is observed after successful renal transplantation in man (28). These data thus indicate that renal function must be taken into account in interpreting plasma glucagon levels in a variety of pathological states. Hyperglucagonemia associated with traumatic shock (29), acute myocardial infarction (30), diabetic ketoacidosis (31), and hyperosmolar coma (32) may, in part, be explained by altered renal hemodynamics associated with these conditions.

Of particular interest were the effects of uremia and dialysis on the glycemic response to exogenous and en-

\footnotetext{
${ }^{3}$ Fisher, M., C. Bastl, R. Sherwin, F. Finkelstein, J. Hayslett, and P. Felig. Unpublished data.
}

dogenous glucagon. As compared to normal controls, undialyzed uremics demonstrated significantly increased glucose responses to physiological increments in plasma glucagon, induced by infusion of this hormone. In contrast, dialyzed uremics responded to exogenous glucagon in a manner comparable to controls (Fig. 5). Furthermore, when the glucagon infusion rate was increased in normals $(6 \mathrm{ng} / \mathrm{kg}$ per $\mathrm{min})$ so as to achieve increments in plasma glucagon comparable to the uremics, the glucose response remained two- to threefold greater in the undialyzed uremics (Fig. 6). In addition to the response to exogenous glucagon, the glycemic response to alanine-stimulated secretion of endogenous glucagon was also greater in undialyzed uremics than in controls or dialyzed uremics. These data thus suggest that uremia is characterized by increased sensitivity to the hyperglycemic effects of physiological increments in glucagon. This augmented sensitivity to glucagon returns to normal after dialysis.

The importance of altered tissue responsiveness to glucagon in uremia is underscored by the differential effects of dialysis on glucose tolerance and plasma glucagon levels. Although, in according with previous reports $(5,9-12)$, dialysis was associated with an improvement in glucose tolerance (Fig. 4), plasma glucagon levels remained unchanged. On the other hand, a direct linear correlation was observed between the 2 -h plasma glucose response to glucose ingestion and the glycemic response to glucagon infusion. These observations suggest that increased tissue sensitivity to the glycemic effects of glucagon is an important factor in uremia-induced glucose intolerance. Improvement in glucose tolerance after chronic dialysis is associated with a return of glucagon sensitivity to normal. It should be noted that previous studies involving bolus injections of $0.15-1.0 \mathrm{mg}$ of glucagon have shown a variable glucose response to glucagon in uremic patients $(1,2,5,33)$. However, the data on the BSDR ${ }_{a}$ glucagon (less than $2 \mathrm{ng} / \mathrm{kg}$ per $\min$ in both the uremics and controls) indicate that such bolus injections represent pharmacological rather than physiological doses of glucagon.

Regarding the mechanism of augmented glucagon sensitivity in uremia, recent studies have demonstrated increased sensitivity to glucagon-induced hyperglycemia in circumstances of acute insulin deficiency (34) and in insulin-withdrawn diabetics (20). On the other hand, physiological increments in glucagon do not alter glucose tolerance in normal subjects, chemical diabetics, or in juvenile-onset diabetics receiving insulin (20). The current findings of hyperinsulinemia in the undialyzed uremics (Fig. 5) indicate that hypersensitivity to glucagon in uremia cannot be ascribed to insulin deficiency. The insulin response to oral glucose (Fig. 4), 
intravenous alanine, and exogenous glucagon (Fig. 5) was increased in the undialyzed uremics, yet was associated with a deterioration in glucose tolerance, suggesting insulin resistance. Whether insulin resistance is a cause or a consequence of augmented tissue responsiveness to glucagon in undialyzed uremics remains to be determined. The current data do not exclude the possibility that uremia results in alterations in hepatic glucagon receptors or in steps subsequent to receptor binding, independent of altered tissue responsiveness to insulin.

Regarding amino acid concentrations in uremia, in accordance with previous observations (22, 35-37), uremic subjects demonstrated increases in plasma, glycine, cystine, citrulline, proline, and taurine, and decreases in tyrosine, valine, and $\alpha$-aminobutyrate. The amino acid pattern in uremia differed from prolonged starvation in which circumstance hypoalaninemia is a striking find (38), thus it suggests that the alterations observed in uremia are not primarily the result of caloric deprivation. While increased glycine and proline levels are seen in protein malnutrition $(39,40)$, the threefold increases in citrulline and cystine in uremic subjects are not observed in protein deficiency $(39,40)$. Furthermore, dialyzed uremics were maintained on a diet of normal protein content $(80 \mathrm{~g})$. These data suggest that nondietary factors contribute to the changes observed in amino acids in uremia. The increased citrulline concentration may reflect alterations in urea cycle activity; elevated arginine levels have also been observed in uremic patients $(22,35-37)$. Particularly noteworthy are the normal levels of serine in the uremic group (Table I). Studies in normal subjects have shown that the kidney is the principal source of plasma serine which is extracted by the liver as well as muscle (41). The failure to observe a fall in serine in uremics suggests either a compensatory reduction in extrarenal uptake, stimulation of extrarenal production, or residual renal release in the uremic group.

Although the infusion of glucagon in the normal subjects failed to alter plasma amino acid levels, the uremics demonstrated reductions in virtually all amino acids (Table I). The glucagon-induced reduction in plasma alanine in the uremic patients exceeded that of all other amino acids. These results suggest increased sensitivity to the gluconeogenic effects of glucagon in uremia. Increased amino acid incorporation into glucose has been observed in perfused rat livers after nephrectomy (42). It should be noted that while dialysis normalized the glucose response to glucagon (Fig. 5), the hypoalaninemic response to glucagon was comparable in dialyzed and nondialyzed patients. These observations suggest that the glycogenolytic and gluconeogenic responses to glucagon may be independently influenced by the uremic state.

\section{ACKNOWLEDGMENTS}

We thank William Sweet, Ralph Jacob, and Andrea Belous for their technical assistance and Tina Spinelli for her secretarial assistance. We are grateful to Kathi Hunt and the staff of the Clinical Research Center at Yale-New Haven Hospital for their efforts in caring for our patients.

This work was supported in part by National Institutes of Health contract NO1-AM-42221, and by National Institutes of Health grants AM 13526 and RR 125.

\section{REFERENCES}

1. Hutchings, R. H., R. M. Hegstrom, and B. H. Scribner. 1966. Glucose intolerance in patients on long-term intermittent dialysis. Ann. Intern. Med. 65: 275-285.

2. Cerletty, J. M., and N. H. Engbring. 1967. Azotemia and glucose intolerance. Ann. Intern. Med. 66: 10971108 .

3. Horton, E. S., C. Johnson, and H. E. Lebovitz. 1968. Carbohydrate metabolism in uremia. Ann. Intern. Med. 68: 63-74.

4. DeFronzo, R. A., R. Andres, P. Edgar, and W. G. Walker. 1973. Carbohydrate metabolism in uremia: A review. Medicine (Baltimore). 52: 469-481.

5. Hampers, C. L., J. S. Soeldner, P. B. Doak, and J. P. Merrill. 1966. Effect of chronic renal failure and hemodialysis on carbohydrate metabolism. J. Clin. Invest. 45: 1719-1731.

6. Spitz, I. M., A. H. Rubenstein, C. Bersohn, C. Abrahams, and C. Lowy. 1970. Carbohydrate metabolism in renal disease. $Q$. J. Med. 39: 201-226.

7. Westervelt, F. B., Jr. 1969. Insulin effect in uremia. $J$. Lab. Clin. Med. 74 : 79-84.

8. Swenson, R. S., D. T. Peterson, M. Eshleman, and G. M. Reaven. 1973. Effect of acute uremia on various aspects of carbohydrate metabolism in dogs. Kidney Int. $4: 267-272$.

9. Lowrie, E. G., J. S. Soeldner, C. L. Hampers, and J. P. Merrill. 1970. Glucose metabolism and insulin secretion in uremic, prediabetic, and normal subjects. J. Lab. Clin. Med. 76: 603-615.

10. Alfrey, A. C., K. E. Sussman, and J. H. Holmes. 1967. Changes in glucose and insulin metabolism induced by dialysis in patients with chronic uremia. Metab. Clin. Exp. 16: 733-740.

11. Davidson, M. B., E. G. Lowrie, and C. L. Hampers. 1969. Lack of dialyzable insulin antagonist in uremia. Metab. Clin. Exp. 18: 387-394.

12. Spitz, I., A. H. Rubinstein, I. Bersohn, A. M. Lawrence, and L. Kirsteins. 1970. The effect of dialysis on the carbohydrate intolerance of chronic renal failure. Horm. Metab. Res. 2: 86-93.

13. DeFronzo, R. A., J. D. Tobin, J. W. Rowe, D. G. Sapir, K. J. Kramer, and R. Andres. 1974. Pancreatic beta cell sensitivity to glucose and tissue sensitivity to insulin: Quantitation of the disturbances in uremia. $J$. Clin. Invest. 53: 18a. (Abstr.)

14. Bilbrey, G. L., G. R. Faloona, M. G. White, and J. P. Knochel. 1974. Hyperglucagonemia of renal failure. J. Clin. Invest. 53: 841-847.

15. Seltzer, H. S. 1971. Oral glucose tolerance tests. In Diabetes Mellitus: Diagnosis and Treatment. S. S. Fajans, and K. E. Sussman, editors. American Diabetes Association, New York. 3: 101-106.

16. Wise, J. K., R. Hendler, and P. Felig. 1973. Evaluation of alpha-cell function by infusion of alanine in normal, diabetic and obese subjects. N. Engl. J. Med. 288 : 487490 . 
17. Huggett, A. S. G., and D. A. Nixon. 1957. Use of glucose oxidase, peroxidase, and $\mathrm{O}$-dianisidine in determination of blood and urinary glucose. Lancet. 2: 368-370.

18. Wise, J. K., R. Hendler, and P. Felig. 1973. Influence of glucocorticoids on glucagon secretion and plasma amino acid concentrations in man. J. Clin. Invest. 52: 2774-2782.

19. Tait, J. F. 1963. Review: The use of isotopic steroids for the measurement of production rates in vivo. $J$. Clin. Endocrinol. Metab. 23 : 1285-1297.

20. Sherwin, R. S., M. Fisher, R. Hendler, and P. Felig. 1976. Hyperglucagonemia and blood glucose regulation in normal, obese and diabetic subjects. N. Engl. J. Med. In press.

21. Snedecor, G. W., and W. G. Cochran. 1967. Statistical Methods. Iowa State University Press, Ames. Iowa. 6th edition. 593 pp.

22. Gulyassy, P. F., A. Aviram, and J. H. Petters. 1970. Evaluation of amino acid and protein requirements in chronic uremia. Arch. Intern. Med. 126: 855-859.

23. Felig, P., R. Gusberg, R. Hendler, F. E. Gump, and J. M. Kinney. 1974. Concentration of glucagon and the insulin: glucagon ratio in the portal and peripheral circulation. Proc. Soc. Exp. Biol. Med. 147: 88-90.

24. Blackard, W. G., N. C. Nelson, and S. S. Andrews. 1974. Portal and peripheral vein immunoreactive glucagon concentrations after arginine or glucose infusions. Diabetes. 23 : 199-202.

25. Duckworth, W. C., M. Heinemann, and K. Kemp. 1975. Insulin and glucagon degradation by kidney. Clin. Res. 23: 318A. (Abstr.)

26. Lefebvre, P. J., A. S. Luyckx, and A. H. Nizet. 1974. Renal handling of endogenous glucagon in the dog: comparison with insulin. Metab. Clin. Exp. 23: 753-761.

27. Lefebvre, P. J., A. S. Luyckx, and A. H. Nizet. 1974. Kidney function as a major factor regulating peripheral glucagon levels. Diabetes. 23 (Suppl. 1) : 343. (Abstr.)

28. Bilbrey, G. L., G. R. Faloona, M. G. White, C. Atkins, A. R. Hull, and J. P. Knochel. 1975. Hyperglucagonemia in uremia: Reversal by renal transplantation. Ann. Intern. Med. 82: 525-528.

29. Lindsey, A., F. Santeusanio, J. Braaten, G. R. Faloona, and $\mathrm{R}$. H. Unger. 1974. Pancreatic alpha-cell function in trauma. JAMA (J. Am. Med. Assoc.). 227: 757-761.

30. Willerson, J. T., D. R. Hutcheson, S. J. Leshin, G. R. Faloona, and R. H. Unger. 1974. Serum glucagon and insulin levels and their relationship to blood glucose values in patients with acute myocardial infarction and acute coronary insufficiency. Am. J. Med. 57: 747-753.

31. Müller, W. A., G. R. Faloona, and R. H. Unger. 1973. Hyperglucagonemia in diabetic ketoacidosis. Its prevalence and significance. Am. J. Med. 54: 52-57.

32. Lindsey, C. A., G. R. Faloona, and R. H. Unger. 1974. Plasma glucagon in nonketotic hyperosmolar coma. JAMA (J. Am. Med. Assoc.). 229: 1771-1773.

33. Cohen, B. D. 1962. Abnormal carbohydrate metabolism in renal disease. Blood glucose unresponsiveness to hypoglycemia, epinephrine, and glucagon. Ann. Intern. Med. 57: 204-213.

34. Alford, F. P., S. R. Bloom, J. D. N. Nabarro, R. Hall, G. M. Besser, D. H. Coy, A. J. Kastin, and A. V. Schally. 1974. Glucagon control of fasting glucose in man. Lancet. 2: 974-977.

35. Salisbury, P. F., M. S. Dunn, and E. A. Murphy. 1957. Apparent free amino acids in deproteinized plasma of normal and uremic persons. J. Clin. Invest. 36: 12271232.

36. Giordano, C., C. De Pascale, D. De Cristofaro, G. Capodicasa, C. Balestrieri, and K. Baczyk. 1968. Protein malnutrition in the treatment of chronic uremia. In Nutrition in Renal Diseases. G. M. Berlyne, editor. Williams \& Wilkins Co., Baltimore. 1: 23-37.

37. Condon, J. R., and A. M. Asatoor. 1971. Amino acid metabolism in uraemic patients. Clin. Chim. Acta. 32: 333-337.

38. Felig, P., O. E. Owen, J. W. Wahren, and G. F. Cahill, Jr. 1969. Amino acid metabolism during prolonged starvation. J. Clin. Inv'est. 48: 584-594.

39. Holt, L. E., Jr., S. E. Snyderman, P. M. Norton, E. Roitman, and J. Finch. 1963. The plasma aminogram in kwashiorkor. Lancet. 2: 1343-1348.

40. Swendseid, M. E., S. G. Tuttle, W. S. Figueroa, D. Mulcare, A. J. Clark, and F. J. Massay. 1966. Plasma amino acid levels of men fed diets differing in protein content. Some observations with valine-deficient diets. $J$. Nutr. 88: 239-248.

41. Felig, P. 1975. Amino acid metabolism in man. Annu. Rev. Biochem. 44 : 933-955.

42. Frohlich, J., J. Schölmerich, G. Hoppe-Seyler, K. P. Maier, H. Talke, P. Schollmeyer, and W. Gerok. 1974. The effect of acute uraemia on gluconeogenesis in isolated perfused rat livers. Eur. J. Clin. Invest. 4 : 453-458. 